\title{
THE EFFECT OF EXTERNAL SHOCKS ON TAX BURDEN: IS IT PERMANENT OR TEMPORARY?
}

\author{
Tunç İNCE1 \\ Furkan BEŞEL ${ }^{2}$
}

\begin{abstract}
The external shocks' effect on tax burden in Turkey is investigated in this study. First, the tax burden concept is explained by conducting empirical literature and responses to tax burden is discussed in the frame of some revolts. In the empirical part of this study, the external shocks' effects on tax burden in Turkey are investigated via unit root tests. First, the stationarity of series is tested by unit root tests which are not considering linearity. The obtained results are showing that series are containing unit root. Later, the linearity of series is researched and the unit root tests which are developed for nonlinear series and taking into account linearity are applied to series since our series are not linear. Similarly, KSS unit root test as one of unit root tests for nonlinear series is showing that series are still having unit root. Since series have unit root, it can be interpreted that external shocks' effects are not temporary and sustainable. Therefore, it is concluded form the results that the intervention for tax burden will be effective and implemented policies will be permanent.
\end{abstract}

Keywords: Tax Burden, Fourier Unit Root Test, Harvey et al. Linearity test, KSS Unit Root Test.

\section{VERGİ YÜKÜ ÜZERINDE DIŞSAL ŞOKLARIN ETKİSi: KALICI MI? GEÇICİ Mİ?}

\section{ÖZ}

Türkiye'de dışsal şokların vergi yükü üzerindeki etkisinin araştırıldığı bu çalışmada öncelikle vergi yükü kavramı açılklanarak ampirik literatür sunulmuş, tarihi süreçte vergi yüküne tepkiler bazı isyanlar çerçevesinde ele alınmıştır. Çalıșmanın ampirik kısmında Türkiye'de vergi yükü üzerindeki dışsal şokların etkisi birim kök testleri ile sorgulanmıştır. Serinin durağanlığı öncelikle doğrusal dışılığı dikkate almayan birim kök testleri sinanmıştır. Elde edilen sonuçlar serinin birim kök içerdiğini göstermektedir. Ayrıca serinin

\footnotetext{
1 Res. Asst., Sakarya University, Faculty of Political Sciences, Department of Public Finance, tince@sakarya.edu.tr.

${ }^{2}$ Res. Asst., Sakarya University, Faculty of Political Sciences, Department of Public Finance, fbesel@sakarya.edu.tr.
} 


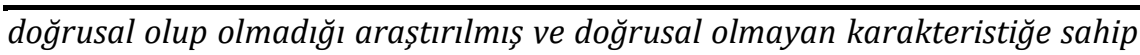
olmasından dolayı doğrusal olmayan seriler için geliştirilmiş birim kök testi uygulanmıştır. KSS birim kök testi sonuçları da diğer testlerin sonuçlarına benzer şekilde serinin birim kök içerdiğini işaret etmektedir. Serinin birim kök içermesi sonucunda vergi yükünün uğradığı dışsal şokların etkisinin kalıcı olacağı ve sürdürülebilir olmadığı söylenebilir. Vergi yüküne yönelik yapılacak müdahalelerin etkili ve uygulanacak politikaların kalıcı olabileceği sonucuna ulaşılmıştır.

Anahtar Kelimeler: Vergi Yükü, Fourier Birim Kök Testi, Harvey vd. Doğrusallık Testi, KSS Birim Kök Testi.

\section{Introduction}

Tax burden can be described simply as "the ratio of person's paid total tax to its income". Tax burden is accepted as one of indicators in determining the tax policy. Many factors such as per capita income, the distribution of the sectors in GDP and tax audits can affect tax burden.

The tax burden is also increasing with the growing financing needs of the state. However, there is also a limit to taxation. This limit leads us to the question: "Is there a sustainability issue in the tax burden?"

In this study, the concepts related to the tax burden will be described first, the responses to tax burden occurred in history will be summarized, and then the impact of external shocks on the tax burden will be tested for Turkey. Analysis covers the 1975-2014 period of data can be obtained.

\section{The Concept of the Tax Burden}

Tax is perceived as a burden because of its impact on individuals and society with its unrequited property (Pehlivan, 2010:158). From a macro perspective, society, and from the micro perspective, the individual income is made possible to be transferred from private to the public sector with tax. Therefore, tax constitutes a reduction in disposable income. While, pressure felled by individuals due to their paid taxes is labelled as subjective tax burden, the relationship between paid taxes and income is expressed objective tax burden (Inaltong, 2012:16). Subjective tax burden changes by special status, tastes and habits of individuals with their income. Objective tax burden, however, is being shaped according to the economic conditions in which the individuals (Tekin, 1990:5).

Although the tax burden is handled in different ways, total tax burden is used in this study. The concept of total tax burden refers all collected taxes burden on the economy. The total tax burden can be 
defined as a ratio of a society's all taxes paid in a certain period (usually one year) to its GDP in that period (Günay, 2007:4-5). The total tax burden can be formulated as "State Tax Revenues Total / GDP" (Pehlivan, 2010:159).

Tax burden can be used in the determination of tax policy and in tax harmonization. In addition, tax burden has a leading feature for policy makers in some issues such as placing and abolition of a new tax, changing tax rate or changing the scope of the exceptions and exemptions.

Tax burden plays a role in the discovery and correction of imbalances occurred in the tax policies together with tax effort and tax optimization. With this aspect, tax burden has an important role as a tool on the economy, reducing the differences in income and providing equity (Tekbaş ve Dökmen, 2007:197).

\section{Responses to Tax Burden}

Taxes contain potential resistance in its inherent as nature. Because it is based on financial difficulties and it is non-refundable. State uses financial and legal force in tax collection based on the sovereignty right. In article 73 of the constitution, fair and balanced distribution of the tax burden is stated as the social objective of fiscal policy. In this context, the expectation of the tax debtors from state is justice, the expectation of the state which is tax claimant from individuals is voluntary compliance.

Showing a reluctant attitude towards taxation of individuals is natural due to reduction in their income and non-refundable nature of tax (Gök, 2007:144). This emerged "tax resistance" due to this and similar reasons led individuals pay as little tax as possible or not to pay any taxes.

Besides, individuals show two different reactions about tax resistance. While the situation where individuals do not react to existing tax burden is labelled as "acceptance", individuals show responses called as active and passive to tax burden.

Passive reactions to tax of individuals can be occurred as preferred to idleness / downtime, reduced consumption, ceases to produce, abandon investment. The most important feature of the active response is disobedience of the individuals to authority. Besides, starting individual reactions cause reactions to turn into a social movement with organization of individuals accordance to their degree of discontent and become into situation threatening the existence of state. This case has entered the literature as tax revolts. 
In the nest section of this study, attempted past revolts against the tax burden in Ottoman, Europe and United States of America will be discussed.

\section{A. Tax Revoltsin Ottoman}

\section{A.1 Patrona Halil Revolt (1730, Istanbul)}

During this period, trades are left in the lurch due to significant increase in the prices with decrease in the value of money and decrease in production with economic recession. The problem of financing the costs of the war waged by Iran was on the agenda when Ottoman Empire was in this economic situation. To defray these expenses, a new tax named "bid'at/innovations" was levied on retail goods to be paid by traders (Aktan et al., 2002:17). Both artisans and Janissaries who has become artisans revolted against this new tax.

Some viziers were killed in the revolt, Mahmud I passed to the throne after Ahmet III. I. Mahmud called Patrona Halil and wanted to learn their wishes. Halil, without any desire for him, has requested the removal of taxes oppressing people (Gök, 2007:158). Thus, the period so-called Tulip Period has ended with this revolt.

\section{A.2 Atçalı Kel Mehmet Revolt (1829-1830, Aydın)}

The people in Aydın with the leadership of Atçalı Kel Mehmet, have rebelled against taxmen who were collecting heavy taxes with the excuse of Ottoman-Russian war and accusing people with mutiny against throne if they disobeyed this taxes (Aktan et al., 2002:17-18).

Atçalı Kel Mehmet rescued people from heavy taxes and yet collected tax as required by law and sent to Istanbul (Gök, 2007:158). This revolt was made against misconduct by officers not against the throne and the sultan.

\section{A.3 Erzurum Revolts (1906)}

The $12.5 \%$ of peasantry's products was collected by tax farming method in the name of tithe. Due the leaseholders' corrupted practices, the rate of tithe tax has reached 30-40\%. (Aktan et al., 2003:6). The main reasons behind the Erzurum revolts are two new tax called as "Personal Tax" and "Animal Taming Tax" collected by government as well as these heavy taxes (Gök, 2007:159).

Nazım Pasha, the governor of this period, sent the $25 \%$ of this collected tax to Istanbul instead of spending for capital's needs. After two new tax with increasing existing tax burden and bribery \& favoritism in government departments, the people of Erzurum was organized to present the petition called as "Privilege of Public" and signed books to governor. The petitions briefly contains "Money will not be sent from Erzurum to Istanbul and all money will be spent for 
local and military needs." and "This region will be excepted from two new taxes decided to be collected.". Although governor said his taking into consideration these requests, he reported this situation as the revolt of public provoked by some people (Aktan et al., 2003:7-8).

The public, who wants the resignation of governor, occupied the telegraph station in order to telegraph directly to palace for the abolition of taxes. Troops during the event did not comply with the orders of superiors and governor and did not attempt to quell the rebellion. For ten days during the events, all shops and schools remained closed even officers did not work. In this process control of the city is passed completely into the public's hands (Aktan et al., 2003:8).

Finally, the government dismissed the governor; instead, Diyarbakir Governor Mehmet Ata was appointed as the replacement. The collection of "Personal Tax" and "Animal Taming Tax" was postponed (Aktan et al., 2003:9).

The new governor has ordered for finding responsible for the rebellion and sending to exile. This has brought people back agitated. Revolt has become riots against order from response to tax. People organized big protest marches; local police and gendarmes opened fire to public and caused the deaths of many (Aktan et al., 2003:10).

\section{A.4 Kastamonu Revolt (1906)}

Not paying taxes of some officers despite living in luxury and increasing the tax burden due to personal taxation has been bothering people. The people reacting to especially Governer Enis Pasha with his living in luxury and not paying any taxes, has wrote a petition containing the situation to palace; however, public complaints have been ignored by palace (Aktan et al., 2003:11).

On the grounds that they have no control over taxation and spending, public boycotted the election of municipal councilors held in late January of 1906 in Kastamonu. People requested the military to control municipal spending by sending representatives to local military commanders in order to explain why people protest.

People of Kastamonu with their unfulfilled requests captured the telegraph station and telegraphed consistently their complaints about taxation. Briefly, they wanted the removal of the additional tax and dismissal of the Governor Enis Pasha. City shopkeepers were closed the shutters to support this resistance (Yllmaz, 2011:129130).

The rebels took delegation came to convince themselves as hostage till the signatories to the petition for dismissal of the 
Governor. Finally, head of provincial treasury and governor have been dismissed as the public wanted (Aktan et al., 2003:12).

\section{A.5 Sinop Revolt (1906)}

Governor's corruptions have actuated the people who have already been overwhelmed from the tax burden. The people who occupied the telegraph station have reported the cruelty and mismanagement of the governor to Istanbul. Meanwhile, they have being expected answers from Istanbul with the slogan of "Long lives the Sultan". Eventually, that are scattered with the telegram containing the dismissal of governor (Aktan et al., 2003:12-13).

Uprisings revolts emerged during this period in Anatolia were stemmed from heavy tax burden, the establishment of new additional tax, luxury livings of senior civil servants and their exemption from taxes. These revolts were resistance movements made against not the central government or palace but more against local managers.

\section{B. Tax Revolts in Europe and USA England) \\ B.1 England Peasants Revolt (Wat Tyler Revolt) (1381,}

After the plague, landowners have imposed new taxes and brought liabilities to the villagers to compensate the huge losses. The third head tax levied to meet oversea military operations in 1337 called as the continuation of centuries of war and the decrease in this tax for poor peasants but not for others have took a great role in peasants revolt.

Riots that erupted in the United Kingdom in 1381 were also hosting the religious factors in addition to the economic factors. Revolt was exhibited the first example of Protestant stream together with hostility to the Catholic Church. Priest named John Waycliffe undertook the religious part of the revolt. Waycliffe has outlined the Protestant movement two hundred years before Luther. He has rebelled to Catholic Church with the voice of the separation of state from religion as ideological. Like Waycliffe, John Ball was also one of the leading Protestant priests of the revolt.

While riot, Wat Tyler was willed by the mayor of London, during his meeting with King Richard The $2^{\text {nd. }}$. Giving concessions to the peasants of the king's men divided the peasants and rebellion ended with a peasant massacre.

John Ball the leader of the rebellion was executed in the presence of Richard $2^{\text {ndafter }}$ the revolt. Although revolt was unsuccessful, this has become the beginning of the end of feudalism 
in United Kingdom (Kısakürek and Kisakürek, 2008:17-19). Head tax was abolished in 1382 to prevent a new revolt (Gök, 2007:152).

\section{B.2 Hampden Operation (1624 - 1629, UK)}

King Charles I. has levied a new tax without the authority of parliament. John Hampden who was deputy in the British parliament has objected to this tax levied without authority from parliament and he was imprisoned in return. People rebelled for this situation and have not paid taxes (Gök, 2007:152). Later, Hampden has also rejected the shipping tax for Royal Navy in 1637 and pioneered to the British Civil War.

In 1629, Charles 1 st The King of England has terminated the parliament due to rising harsh criticisms. This period where parliament has not been convened for 11 years is called as "The Personel Rule" (Eleven Years Tyranny) (Donoghue, 1997:37).

\section{B.3 Stamp Tax Revolt (1765, British Colonies)}

In 1765, England has brought the Stamp Act to be implemented in the colonies. Thus, colonies have come together in response and requested from The King of England to be fairer in taxes by accepting Declaration of Rights. The King of England lifted the stamp duty due to reactions, but he took the decision to have the full authority in all matters relating to the colony. Colonies reacted again for new taxes levied in 1767 and England abolished all other taxes (paper, paint, glass and fabric) except tea tax.

The main reason for the reactions to the stamp tax is the damage to independence and impartiality of the courts made by the law's provisions on preventing violations. Accordingly, those who violate the law were decided to be judged the Admiralty Courts in Nova Scotia which were known to be pro-government. Furthermore, those having judgement of jury were decided to be tried without a jury in the court. People have reacted to this situation and rebelled (Birecikli, 2011:86).

\section{B.4 Boston Tea Party (1773, British Colonies)}

People have rebelled in 1767 for new taxes levied by England on certain goods related with imports and 3 people died in the incidents (Boston Massacre). These taxes were later removed. Yet, tax levied on only tea was kept as a symbol of sovereignty right. Americans have opposed the tax, since they thought they would give another opportunity to England to put new taxes if they accept the tea tax (Gök, 2007:155). Besides, price of tea in the colonies has doubled because of taxes, demand for tea has decreased and thereby, tea stocks in the UK have increased (Birecikli, 2011:86). 
British parliament has levied a law to leave entire rights of tea trade coming from colonies to East India Company and has created a monopoly in this area. American traders were deprived from carrying and selling British tea by this privilege (Kısakürek and Kısakürek, 2011:94).

Despite some colonies were harshly against, the public response has been very hard when The British has requested to release tea brought to Boston Harbor. A group of Americans in the leadership of Samuel Adams have disguised as Mohawk and emptied tea in ships into the sea by attacking the ships loaded with tea in the night of December 16, 1773. Pouring tea into the sea led waters of Boston Harbor to change into tea color due to shallow water. Therefore, this revolt was named as Boston Tea Party.

After Boston Tea Party, Virginia Colony has called other colonies to congress in order to defend common interests and rights. 9 of 13 colonies have answered to first meeting and the first step in the road to independence of the colonies was taken (Birecikli, 2011:86).

\section{B.5 Shays Revolt (1786-1787, USA)}

US have fallen into unstable conditions after the War of Independence. States began to act as independent states and has taken some decisions without thinking about the future of the republic. Almost all of them used a different and worthless currency. States have received taxes from goods imported from other states (Birecikli, 2011:90). In fact, they took taxes from citizens of other states. The collected taxes made people unable to pay their debts, some farmers lost their assets and some even have received prison sentences (Yegin, 2011:4).

Britain has refused to open the trade routes of great importance for the colonies. State legislators have refused to pay the debts they had during independence, even they have made legal arrangements saving themselves from debt obligations. Some state legislatures were beginning to think the path of armed struggle for liabilities.

In 1786, Captain Daniel Shays with in addition to thousands of farmers have rebelled against the state government ofBoston in Massachusetts (Birecikli, 2011:90). After, the rebels turned to the ammunition depot in Springfield. Despite the lack of power of central government and the states, revolt was suppressed by voluntary associations created later. This situation has become an important 
signal for America's founders that a larger revolt could not be suppressed by transitional measures (Yegin, 2011:4).

\section{B.6 Whisky Revolt (1794, USA)}

Alexander Hamilton, America's first treasury minister, has led to the enactment of the whiskey tax due whiskey is a producer of luxury and impair the morals and health of society (Turan and Yurdakul, 2009:4). This corresponds to $1.5 \$$ for an American family who drinks 6 gallons of whiskey per year on average. Hamilton has calculated that $800,000 \$$ would be into the coffers of the treasury by this tax.

However, whiskey was seen as a vital necessity for farmers in the states of Pennsylvania, Virginia and Carolina. Even in western Pennsylvania cities, whiskey was used instead of money. Therefore, farmers have shown great response to this tax (Ladenburg, 2007:2022). The use of violence in protests led response action to transform into the tax revolt and Tom Tinker who became notorious with killing tax payers has taken the lead of this revolt (Gök, 2007:156).

\section{B.7 Fries Revolt (1799, USA)}

In the period of John Adams who was the first vice president and second president of USA, The French has appeared in some looting actions on the USA's trade roads. Besides, the desecration of the USA's rights in open sea and bloody wars in Europe involving French have created the idea into USA that a war with the French was inevitable. New treasury minister Hamilton, ensured a new wealth tax (house tax) in line with the needs of the army and has ignited a revolt (Davis, 1899:1). After the increase in arrests and violence, Adams forgave the rebels and the revolt has ended. Thomas Jefferson was selected as president by the election held in 1800 and he demolished the taxes advised and applied by Alexander Hamilton (Gök, 2007:156).

Fries revolt is related with previously occurred Shays and Whiskey revolts and these three revolts have an important warning given to the Republicans in the United States. Both three rebellions started due to basically taxes with an attempt to be taken in an unfair or illegal way. Fries revolt happened in Buck and Northampton in fall and winter months of 1798-1799 and was mentioned with John Fries name who has rebelled against federal authorities (Davis, 1899:3).

\section{B.8 Great Depression Tax Opposition (1929, USA)}

The greatest reason behind the great depression tax opposition was increasing tax burden due to recession. Before depression in 1920s, American people have experienced the 
relatively positive effects of tax system by reduction in federal tax rates by almost half for each income group.

Until the Great Depression, the economy has grown rapidly by the impact of tax cuts. However, the wealth tax as a major part of the tax burden has begun to show results especially after excessive growth of cities and the increase in borrowing. In the early 1920s high wealth taxes and the extension of the tax on the base, could be tolerated due to showed growth performance. Even taxpayers have also seemed willing to pay increased wealth tax because of increasing fees, revenues and stock market by increasing value of house prices and transactions. However, the tax burden began to increase with the crash of stock market and the beginning of the great depression. Thus, reactions to tax burden, tax crimes and submerged banks have evolved to tax resistance movement. In the long-term, resistance has become successful, wealth taxes have been reduced, the arrangements were made for the tax limitations and tax burden have been reduced (Thornton and Weise, 2001:97-99).

\section{B.9 Poujade Operation (1953, France)}

In June 1953, citizens of Lot in France have managed a meeting with the early notification of controls to be made by tax inspectors. The resistance to the inspector was decided against coming inspectors at this meeting. The next day, the people have shown a strong resistance against the inspectors and inspectors were forced to leave the city helplessly by this resistance. The person organizing this resistance was Pierre Poujade who was operating stationery shop and was also a member of parliament. Later, this little beginning spread through France and has become a great movement (Bulutoğlu, 1958:174-176).

The decrease in the profits of small businesses and craftsmen due to deflationary policies was accepted as one of the significant reasons behind Poujade movement (Gök, 2007:152). Additionally, the tax burden has increased noticeably through bringing new indirect tax liabilities to artisans and craftsmen. Moreover, the spots where this movement spread through places with declining economic conditions where owners were generally needy and population were decreasing drastically. The beginning centralization of trade and receiving incentives from the state of large companies have made small businesses and craftsmen to shrink and caused their bankruptcy (Bulutoğlu, 1958:174-176). 


\section{B.10 Capitation Tax Revolt (1990, UK)}

Head tax was an application which had a great damage to political career of Margaret Thatcher in England. Head tax in 1990 was replaced by removed local government taxes but it created greater tax burden on tax payers than local government tax. Besides, levied tax was collected insensitively and equally for everyone without considering income levels of people. Therefore, tax was considered unfair.

The British went to streets to react to this tax and clashed with police. Several of the demonstrators were taken into custody and taken to prison. Even some imprisoned protesters began a hunger strike in Strangeways Prison. Officials tried to fry onions next to prisoners when they failed to discourage prisoners from hunger strike (Gök, 2007:153).

\section{Literature Review}

Empirical literature related to tax burden is summarized into table below.

Table 1: The Literature Abstract of Tax Burden's Stability Study

\begin{tabular}{|c|c|c|c|c|}
\hline $\begin{array}{c}\text { Giles and } \\
\text { Caragata } \\
(2001)\end{array}$ & New Zealand & $\begin{array}{c}1968- \\
1994\end{array}$ & $\begin{array}{c}\text { ADF - } \\
\text { KPSS Tests }\end{array}$ & $\mathrm{I}(1)$ \\
\hline $\begin{array}{l}\text { Çetintaş } \\
\text { andVergil } \\
(2003)\end{array}$ & Turkey & $\begin{array}{c}1971- \\
2000\end{array}$ & ADF Test & $\mathrm{I}(1)$ \\
\hline $\begin{array}{l}\text { Ay, Köser } \\
\text { andSugözü } \\
\text { (2005) }\end{array}$ & Turkey & $\begin{array}{c}1968- \\
2001\end{array}$ & PP Test & $\mathrm{I}(1)$ \\
\hline $\begin{array}{c}\text { Mamatzakis } \\
\text { (2005) }\end{array}$ & Greece & $\begin{array}{c}1960- \\
2003\end{array}$ & $\begin{array}{c}\text { ADF - } \\
\text { KPSS Tests }\end{array}$ & $\mathrm{I}(0)$ \\
\hline $\begin{array}{l}\text { Han andWang. } \\
\text { (2007) }\end{array}$ & 25 Countries & $\begin{array}{c}1972- \\
2000\end{array}$ & $\begin{array}{l}\text { ADF - PP - } \\
\text { KPSS Tests }\end{array}$ & $\begin{array}{c}\text { Luxembourg, } \\
\text { Germany, } \\
\text { Sweden and } \\
\text { Switzerland } \\
\text { I(0), other } 21 \\
\text { countries I(1) }\end{array}$ \\
\hline $\begin{array}{l}\text { Açıkgöz } \\
\text { (2008) }\end{array}$ & Turkey & $\begin{array}{c}1968- \\
2006\end{array}$ & ADF Test & $\mathrm{I}(1)$ \\
\hline $\begin{array}{l}\text { Geys and } \\
\text { Vermeir } \\
(2008)\end{array}$ & USA & $\begin{array}{l}1959- \\
2006\end{array}$ & ADF Test & $\mathrm{I}(0)$ \\
\hline $\begin{array}{c}\text { Yurdakul } \\
(2008)\end{array}$ & Turkey & $\begin{array}{c}1985- \\
2006\end{array}$ & ADF Test & $\mathrm{I}(1)$ \\
\hline
\end{tabular}




\begin{tabular}{|c|c|c|c|c|}
\hline $\begin{array}{l}\text { Mangır and } \\
\text { Ertuğrul } \\
\text { (2012) }\end{array}$ & Turkey & $\begin{array}{c}1988- \\
2011\end{array}$ & $\begin{array}{c}\text { ADF - PP } \\
\text { Tests }\end{array}$ & $\mathrm{I}(1)$ \\
\hline Elgin (2012) & 152 Countries & $\begin{array}{c}1999- \\
2007\end{array}$ & $\begin{array}{l}\text { Panel Data } \\
\text { Analysis } \\
\text { ADF Test }\end{array}$ & $\begin{array}{c}\text { Direct Taxes } \\
\text { I(1) } \\
\text { Indirect Taxes } \\
\text { I(2) }\end{array}$ \\
\hline $\begin{array}{l}\text { Ay, Sugözü and } \\
\text { Erdoğan } \\
(2014)\end{array}$ & Turkey & $\begin{array}{c}1985- \\
2012\end{array}$ & ADF Test & $\mathrm{I}(1)$ \\
\hline
\end{tabular}

In the empirical studies about tax burden, tax burden series contains generally unit root and it is I(1) as can be seen. Tax burden seems non-stationary for all studies in Turkey.

\section{Data and Methodology}

In this study analyzing the effect of external shocks on the tax burden in Turkey, Total Tax Burden (TAX) variable is used as an indicator of tax burden. The data of this variable covers the period 1975-2014. The data is gained from Ministry of Development and Economic and Social Indicators Revenue Administration database.

The movement of total tax burden in Turkey is shown in the Figure 1.

TAX

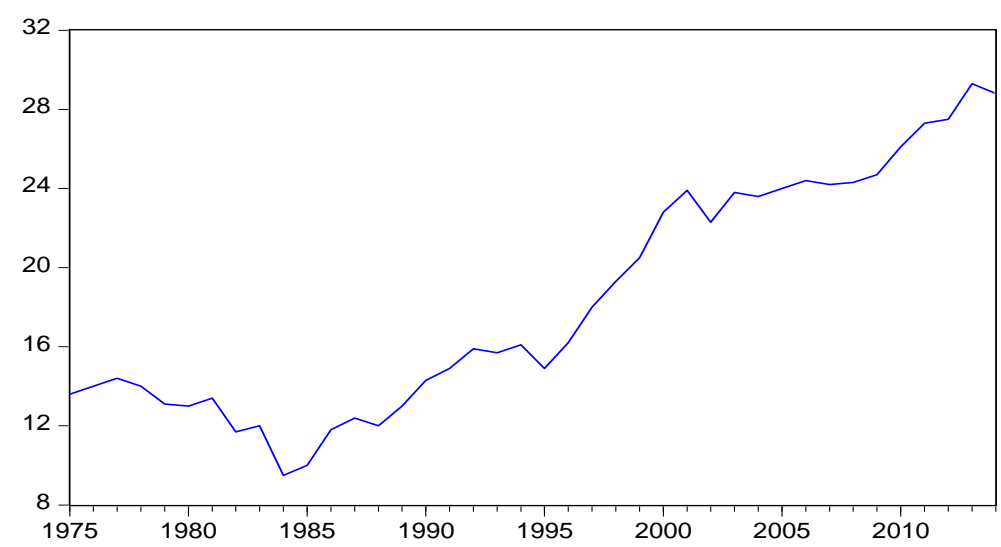

Figure 1. The Development of Tax Burden in Turkey (1975-2014)

Source: Created by us with the data obtained from Ministry of Development and Economic and Social Indicators Revenue Administration

When looked at the evolution of Total Tax Burden, it can be interpreted that increasing trend dominated almost the whole 
evolution. The Total Tax Burden in 1975, the start date of our study, which was $13.6 \%$, fluctuated between $\pm 3 \%$ till 1996. Total Tax Burden has increased in 1997 and reached 23.9\% in 2001 and decreased to $22.3 \%$ in 2002 . Then, it continued its increasing and reached $28.8 \%$ in 2014 .

In study, the effect of external shocks on the tax burden will be analyzed by unit root tests. First, mainstream unit root tests will be implemented; later the linearity of series will be tested. Since mainstream unit root tests assume that all series are linear; unit root tests which are taking into account non-linearity will be performed for non-linear series according to linearity test results.

\section{Root Test}

A. Augmented Dickey Fuller and Phillips Perron Unit

Dickey Fuller test is shown in theory and practice as:

$$
\Delta Y_{t}=\delta Y_{t-1}+u_{t}
$$

with constant and trend,

$$
\Delta Y_{t}=b_{0}+\delta Y_{t-1}+u_{t}
$$

with constant and without trend,

$$
\Delta Y_{t}=b_{0}+b_{1} t+\delta Y_{t-1}+u_{t}
$$

with constant and regressions with trend. Moreover, $\tau$ or DF statistics and MacKinnon critical values are obtained.

If error term $u_{t}$ contains autocorrelation, equation 3 is constructed as:

$$
\Delta Y_{t}=b_{0}+b_{1} t+\delta Y_{t-1}+\alpha_{i} \sum_{i=1}^{m} \Delta Y_{t-i}+u_{t}
$$

Here, regressive difference terms are used and the number of these terms is generally determined by empirically. The main purpose in constructing the equation by this form is adding terms into the equation which make error term without autocorrelation problem. The null hypothesis is $\mathrm{P}=1$ or $B=0$. The null hypothesis is "Y contains unit root", thus $\mathrm{Y}$ is not stationary. The test becomes "Augmented Dickey Fuller" (ADF) test when DF test is applied to models as in the equation (4). The critical test statistics values of these tests are same (Tarı, 2010:388-390). 
Phillips Perron (PP) test is more flexible than DF and ADF tests according to hypothesis about error term. For DF and ADF tests, error term is independent and with constant variance. It should be noted when using this methodology is the certainty on not having correlation between error terms and whether constant variances. PP has extended his hypothesis about DF's error terms. This regression expresses this situation much better (Tarı, 2010:400):

$$
\begin{gathered}
Y_{t}=a_{0}+a_{1} y_{t-1}+u_{t} \\
Y_{t}=a_{0}+y_{t-1}+a_{2}(t-T / 2)+u t
\end{gathered}
$$

In this regression, $\mathrm{T}$ and $\mathrm{u}_{\mathrm{t}}$ represents the number of observations and distribution of error terms, respectively. The expected average of this error term is equal to 0 . However, there is a homogeneity assumption here that there shouldn't serial correlation between error terms. In this regard, the independence and homogeneity assumptions of DF test are not considered in PP test. On the contrary, the weak dependence and heterogeneous distribution of error terms are accepted. Therefore, Phillips-Perron did not take into account the limitations about error terms' hypotheses in developing DF t-statistics. (Tarl, 2010:400).

ADF and PP unit root test results are shown in Table 2.

\begin{tabular}{|c|c|}
\hline ADF Test & TAX \\
\hline Constant & $0.675510(0)[0.9900]$ \\
\hline Constant+Trend & $-2.087289(0)[0.5365]$ \\
\hline PP Test & TAX \\
\hline Constant & $0.624493(2)$ \\
\hline Constant+Trend & $-2.087289(0) \quad[0.5365]$ \\
\hline
\end{tabular}

Table2: ADF and PP Unit Root Tests Results

Notes: Suitable lag length in ADF test is determined according to Schwarz Information Criterion (SIC) and showed in the parenthesis. The numbers in the square brackets are showing p-values. In PP test, kernel method and bandwidth values are determined with "Barlett Kernel" and "Newey West Bandwidth", respectively.

According to ADF and PP test results, TAX series is not stationary and contains unit root at level for both models. 


\section{B. Zivot Andrews Unit Root Test}

The studies considering structural breaks have begun with Perron (1989). Perron have noticed the changes in averages of macroeconomic values due to 1929 Great Depression and 1973 Oil Crisis and included these events in to his unit root tests by generating dummy variables for related years. He determined that when dummy variables were included into the series, non-stationary series had become stationary. However, test statistics developed by Perron is depending on the situation where the structural break dates are exogenous and determined previously.

Zivot and Andrews (1992) have developed test statistics of Perron by modifying into the situation where the structural break dates are endogenous and not determined previously. Zivot and Andrews (1992) have suggested three models to examine the unit root under the structural breaks (Zivot and Andrews,1992:254):

$$
\begin{aligned}
& Y_{t}=\mu^{A}+\theta^{A} D U_{t}(\lambda)+\beta^{A} t+\alpha^{A} y_{t-1}+\sum_{j=1}^{k} c_{j}^{A} \Delta y_{t-j}+e_{t} \\
& Y_{t}=\mu^{B}+\beta^{B}+\gamma^{B} D T_{t}^{*}(\lambda)+\alpha^{B} y_{t-1}+\sum_{j=1}^{k} c_{j}^{B} \Delta y_{t-j}+e_{t} \\
& Y_{t}=\mu^{C}+\theta^{C} D U_{t}(\lambda)+\beta^{C} t+\gamma^{C} D T_{t}^{*}(\lambda)+\alpha^{C} y_{t-1}+\sum_{j=1}^{k} c_{j}^{C} \Delta y_{t-j}+e_{t}
\end{aligned}
$$

$\mathrm{T} \lambda$ represents the possible break date. In equation (7), if $\mathrm{T} \lambda<\mathrm{t}$, $\operatorname{DU}_{\mathrm{t}}(\lambda)$ is a dummy variable with the value 1 and the value 0 in other cases. In equation (8), if $\mathrm{t}>\mathrm{T} \lambda, D T_{t}^{*}(\lambda)$ is a dummy variable with the value $\mathrm{t}-\mathrm{T} \lambda$ and the value 0 in other cases. Equation (7), equation (8) and equation (9) is testing break in constant, break in trend and break in both constant and trend, respectively.

During application, dummy variables are generated by accepting each year in observation period as a possible structural break date and then $t$ statistics of $\alpha$ value are calculated. When this process is applied to all observation period, the year with the smallest t-statistics is determined as a year with the break.

$\mathrm{T}$-statistics is compared with the critical values created by Zivot and Andrews. If absolute value of $t$-statistics is smaller than the critical values, the null hypothesis which claims that series contains unit root is accepted. If absolute value of t-statistics is greater than the critical values, the null hypothesis is rejected and alternative 
hypothesis which implies the stationarity of series with structural break is accepted (Barışık and Çevik, 2008:12).

Table 3: ZA Unit Root Test Results

\begin{tabular}{|c|c|c|}
\hline 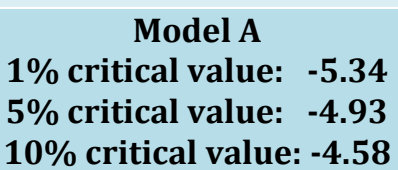 & -3.530394 & 1982 \\
\hline 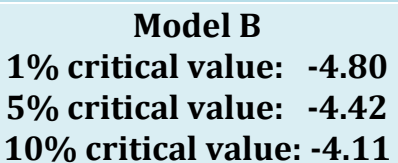 & -4.10199 & 1982 \\
\hline 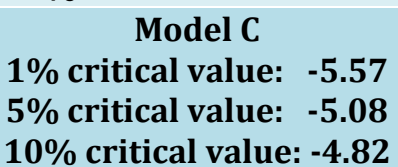 & -4.213247 & 1982 \\
\hline
\end{tabular}

According to ZA unit root test results, the null hypothesis which claims that series has a unit root, cannot be rejected since absolute value of t-statistics obtained from Model A, B and C is smaller than the critical values. Similar with the ADF and PP tests, TAX series contains unit root at level and is not stationary.

\section{Fourier Unit Root Test}

By the Fourier unit root test imparted to literature by Christopoulos and Leon-Ledesma (2010), major changes in deterministic terms were modelled via trigonometric methods. Test is sensing hard and soft breaks when applied with determining appropriate frequency. Date, number and form of break do not affect the power of the test (Yilanci and Eris, 2012:210). The null hypothesis of Fourier Unit Root Test claims the unit root in series and alternative hypothesis claims stationarity of series.

In Fourier unit root test, primarily, suitable frequency $(\mathrm{k})$ is determined (minSSR), and then F statistic is calculated for the model established at an appropriate frequency. If $\mathrm{F}$ statistics is greater than the critical values, trigonometric terms are agreed significant. In the next stage, the stationarity of Residual Square of model established at suitable frequency $\tau_{\mu}(k)$ is tested. If the calculated $\tau$ statistics is smaller than the critical values, the null hypothesis cannot be rejected $^{2}$. The Fourier unit root test result is given in the Table 4. 


\section{Table4: Fourier Unit Root Test Results}

$$
F_{\mu}(k) \quad \tau_{\mu}(k)
$$

\begin{tabular}{|l|l|l|l|l|} 
TAX & 283.71 & 1 & 70.17 & -0.71 \\
\hline
\end{tabular}

Note: The critical values compared with $F_{\mu}(k)$ are obtained from Becker et al. (2006) and they are 4.133, 4.929 and 6.730 for $10 \%, 5 \%$ and $1 \%$, respectively. The critical values compared with $\tau_{\mu}(k)$ are obtained from Christopoulos and LeonLedesma (2010) and they are $-3.52,-3.85$ and -4.43 for $10 \%, 5 \%$ and $1 \%$, respectively.

The suitable frequency for TAX series is determined as 1 by using minSSR. The model with the appropriate frequency is estimated and F-statistic is calculated as 70.17. Since F-statistics is greater than the critical values at all significance levels, the trigonometric terms used in model are significant. Therefore, unit root test result will give statistically significant result. The stationarity of Residual Square of model established at suitable frequency is tested by $\tau_{\mu}(k)$ and $\tau$ statistics is calculated as -0.71 . Since absolute value of $\tau$ is smaller than all critical values at all significance levels, null hypothesis cannot be rejected. Thus, series contains unit root and is not stationary. How estimations of Fourier functions catch the deviations can be seen in Figure 2 .

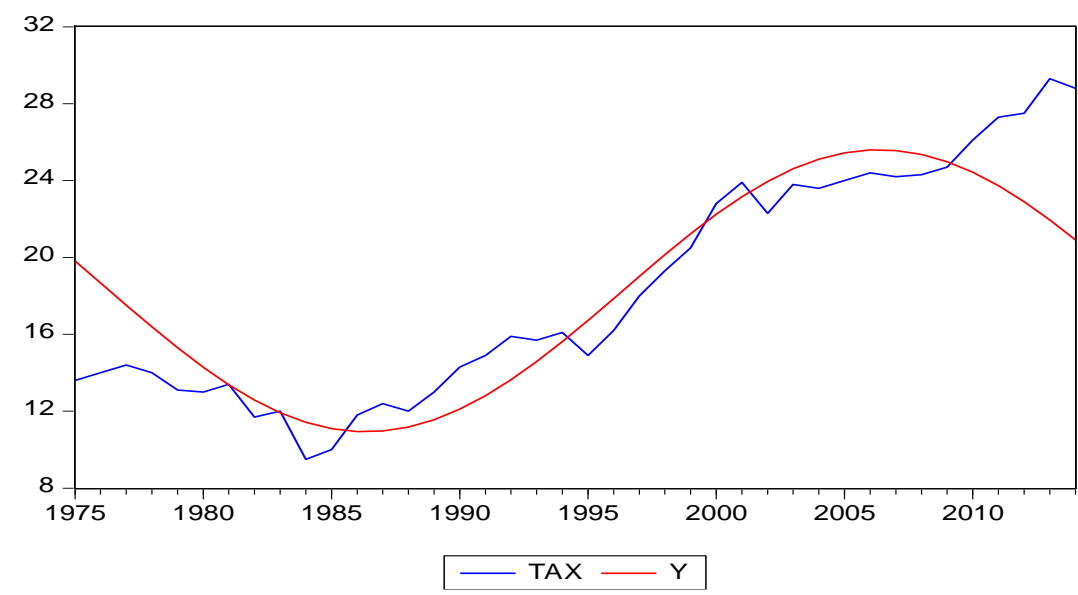

Figure 2: Fourier Functions

In irrespective manner of whether the series is linear, stationarity level of series is determined via ADF, PP, ZA and Fourier 
Unit Root Tests and the result is reached that series is not stationary and contains unit root.

After obtaining mainstream unit root test results, the linearity of TAX series will be tested and if the series is not linear, its stationarity will be investigated via KSS Unit Root Test which is developed for non-linear series.

\section{Harvey et al. (2008) Linearity Test}

The non-linearity of economic series may be based on several reasons arising from their characteristic features. For example, while the non-linearity in interest rates may stem from operation cost, the reasons behind the non-linearity in stock index may be the presence of heterogeneous players, players' different evaluations of new information coming into market (asymmetric information) and shortcomings in the market (Yllancı, 2013:2).

Linearity test imparted to literature by Harvey et al. (2008) contains two different linearity tests by assumption of the stationarity of series and containing unit root. The weighted average of these two tests creates Harvey et al. linearity test (Yllancl, 2013:6). The null hypothesis of the test is linearity of the series and the alternative hypothesis claims non-linearity.

If the test statistics calculated from Harvey et al. test is smaller than the critical value prepared by Harvey et al.(2008), null hypothesis will be rejected. In this situation, the series is linear ${ }^{2}$. The results of Harvey et al. Linearity Test are shown in the Table 5.

Table5: Harvey et al.Linearity Test Result

\begin{tabular}{|l|c|c|c|c|}
\hline & $\begin{array}{l}\text { Calculated } \\
\text { t-stat }\end{array}$ & \multicolumn{3}{|c|}{$\begin{array}{l}\text { Critical Values Accordance to } \\
\text { Significance Levels }\end{array}$} \\
\hline Variable & t-stat & $\mathbf{\% 1}$ & $\mathbf{0 5}$ & $\mathbf{0 1 0}$ \\
\hline TAX & 5.34 & 2.53 & 2.43 & 2.38 \\
\hline
\end{tabular}

Note: Critical values are obtained from Harvey et al. (2008).

Since test statistics calculated from linearity test is greater than the critical values at all significance level, null hypothesis is rejected. Therefore, tax burden series has a nonlinear characteristic.

Due TAX series is nonlinear, its stationarity will be test via KSS Unit Root Test developed for nonlinear series.

\section{E. KSS Unit Root Test}

Kapetanios et al (2003) imparted the unit root test to literature that null hypothesis of this test is series with unit root and 
the alternative hypothesis is stationarity and being suitable for exponential transition autoregressive process of series ${ }^{2}$. In Table 6, KSS Unit Root Test results are stated.

Table6: KSS Unit Root Test Result

\begin{tabular}{|l|c|c|c|c|}
\hline & $\begin{array}{c}\text { Calculated } \\
\text { t-stat }\end{array}$ & \multicolumn{3}{c|}{ Critical Values Accordance to } \\
Significance Levels
\end{tabular}

Not: Critical values are obtained from Kapetanios et al. (2003).

Since test statistics obtained from KSS Unit Root Test is smaller than the critical values, null hypothesis of non-stationarity of series cannot be rejected. Thus, TAX series contains unit root and is not stationary.

Similarly with other unit root test results, KSS unit root test applied for nonlinear series indicates the non-stationarity of series. As a result, all unit root test results are showing the non-stationarity and containing unit root of series.

Due series contains unit root, it can be interpreted that the effect of external shocks on series will be permanent and tax burden is not sustainable. Therefore, interventions and implemented policies will be effective on tax burden. Consequently, the effects of policies on the tax burden will be permanent.

\section{CONCLUDING DISCUSSION}

In this study investigating the effect of external shocks on tax burden, first the concept of tax burden is discussed and the responses of people in the period of increasing tax burden is investigated in the scope of tax revolts for different countries. The studies related to tax burden is stated as the literature review.

In order to conduct econometric analysis, Total Tax Burden data set is used as tax burden indicator. As a result of empirical analysis, tax burden series is not stationary and contains at level accordance to both unit root tests which do not consider linearity and KSS Unit Root Test developed for nonlinear series. The obtained results coincide with the applied studies for Turkey.

Carrying stationarity feature of series depends of statistically not varying in time of mean and variance. However, according to unit root test results, it is achieved that series do contain unit root. İt can be interpreted that the effect of external shocks on series is permanent and it is not sustainable. Tax burden series do not resolve 
the effect of external shocks, thus it does not have sustainability characteristic in the absence of external intervention. Considering the responses of people against excessive tax burden changing into revolts throughout the history, the result of unsustainability of tax burden is a vital finding for policy makers.

ZA test with structural break indicates the year 1982. The year 1982 is carrying the traces of "1980 Military Coup" happened two years earlier and affected Turkey in all areas. In this period, Turkey abandoned the import substitution system and has made the transition to an export-oriented economic system. Public expenditure is increased in order to support sectors with the external competitiveness power and the tax burden has entered a steady upward trend after this period.

As a result, the interventions and implemented policies on tax burden will be effective, since the effect of external shocks on tax burden is determined permanent. This mustn't be forgotten that the responses of people against tax burden may have severe results as in the history and policy makers must consider these issues.

\section{REFERENCES}

AKTAN, Coşkun Can, Dilek Dileyici, Özgür Saraç (2002), "Osmanlı Tarihinde Vergi İsyanları-I", Süleyman Demirel Üniversitesi İktisadi ve İdari Bilimler Dergisi, Cilt:7, Sayı:2, ss:1-20.

AKTAN, Coşkun Can, Dilek Dileyici, Özgür Saraç (2003), "Osmanlı Tarihinde Vergi İsyanları-II", Süleyman Demirel Üniversitesi İktisadi ve İdari Bilimler Dergisi, Cilt:8, Sayı:1, ss:1-25.

BARIŞIK, Salih ve Emrah İsmail Çevik (2008), "Hysteresis Effect In Unemployment: Long Memory Model”, İş Hukuku ve İktisat Dergisi, Vol:9, No:4

BIRECIKLİ, İhsan Burak (2011), "Foundation of America and the Relationship between USA and Europe (1776-1876)", History Studies, Relationships of the USA and The Great Middle East Special Issue, 81-103.

BULUTOĞLU, Kenan (1958), "Typical Reaction to the Tax Poujade Operation", Istanbul University Journal of Center for Public Finance Researches Conferances, volume 4, issue 1,173-179.

DAVIS, William W. H. (1899), "The Fries Rebellion 1798-99", Doylestown Publishing Company, Doylestown, Penna. https://ia600801.us.archive.org/4/items/abt5123.0001.001.umich.e du/abt5123.0001.001.umich.edu.pdfAcces Date: 13.03.2015. 
DONOGHUE, John (2006), "Radical Republicanism In England, America, And The Imperial Atlantic, 1624-1661", University of Pittsburgh, 2006.

GÖK, Kerim (2007), "Evolution of Tax Resistance, Marmara University, Journal of EAS, volume 22, issue 1, 143-163.

GÜNAY, Kerem (2007), "The Case Study of Calculation Tax Burden and Tax Capacity in Turkey, PwC Turkey, Istanbul.

INALTONG, Ceyhan (2012), "Tax Burden: The Comparison of Turkey and OECD Countries", Tax World, issue 369, 16-30.

KAPETANIOS, George (2005), "Unit-Root Testing Against The Alternative Hypothesis Of Up To m Structural Breaks", Journal of Time Series Analysis, Vol: 26, No: 1, pp.123-133.

KISAKÜREK, Evin Esmen ve Arda Kisakürek (2008), "Ours: Muslim Roman Empire", Anatolia Based World History. https://sites.google.com/site/ekitdunyatarihidevam2/home/14kitapAcces Date: 20.01 .2015

KISAKÜREK, Evin Esmen ve Arda Kisakürek (2011), "Ours: Enlightenment", Anatolia Based World Historyhttp://www.dunyatarihi.com/images/kitaplar/23.\%20kitap\%20resimsiz\%20(17551785).pdfAcces Date: 27.05.2015.

http://www.gib.gov.tr/fileadmin/user upload/VI/GBG/Tabl o 14.xls.htm Acces Date: 27.03.2015.

LADENBURG, Thomas (2007), "The Whiskey Rebellion", Digital History. http://www.digitalhistory.uh.edu/teachers/lesson plans/pdfs/unit3 5.pdfAcces Date: 09.03.2015.

PEHLIVAN, Osman (2010), "Public Finance”, Derya Bookstore, Trabzon.

SARUÇ, Naci Tolga (2013), "Tax Compliance: Current Progress in Turkey and the World", Akademisyen Bookstore, Ankara.

SCHWERT, G. William (1988), "Tests For Unit Roots: A Monte Carlo Investigation", NBER Technical Working Paper Series, Vol.7(2), pp.147-159.

TARI, Recep (2010), “Econometrics”, Extended Sixth Edition, Umuttepe Publication, Kocaeli.

TEKBAŞ, Abdullah ve Gökhan Dökmen (2007), "Regional Distribution Of Tax Burden in Turkey", Journal of Public Finance, no 153, July-December 2007, 195-213.

TEKIN, Ahmet (1990), "Tax Burden in Eskişehir From the Point of Income Tax", Master's Thesis, Anatolia University Social Sciences Institute. 
THORNTON, Mark ve Chetley Weise (2001), "The Great Depression Tax Revolts Revisited", Journal of Libertarian Studies, Vol:15, No:3, 65-105.

TURAN, Deniz ve Ali Yurdakul (2009), "Sin Tax And Effectiveness As An Instrument For Prevention Of Harmful Habits" Journal of Economic Sciences, issue 1, no 2.

YEGIN, Mehmet (2011), "Yesterday and Today of American Federalism", Internation Strategic Research Organization, No:8.

YILANCI, Veli (2013), "Lecture Notes of Econometrics Seminar", Sakarya University, 1-104.

YILMAZ, Mehmet Serhat (2011), “II.Meşrutiyet Öncesi Kastamonu'da Bir Ayaklanma Girişimi (1906)”, Karadeniz Araștırmaları, Yaz 2011, Sayı:30, ss:123-142.

ZIVOT, Eric ve Donald W.K. Andrews (1992), "Further Evidence of the Great Crash, The Oil-Price Shock and The Unit Root Hypothesis", Journal of Business and Economic Statistics, Vol: 10, No: 3; 251-270. 